\title{
METHOD FOR PREDICTING THE DURABILITY OF ELECTRONIC EQUIPMENT
}

Zhadnov V. V. - PhD, Associate Professor, Professor of Department of Electronic Engineering, National Research university "Higher ichool of economics", Moscow, Russia.

Kulygin V. N. - Master of Engineering and Technology, Post-graduate Student of the Moscow Institute of Electronics and Mathematics A. N. Tikhonov National Research University "Higher School of Economics", Moscow, Russia.

Zotov A. N. - Master of Engineering and Technology, post-graduate student of the Moscow institute of electronics and mathematics A. N. Tikhonov National Research University "Higher School of Economics", Moscow, Russia.

\section{ABSTRACT}

Context. Constant growth of spacecraft operating life requirements leads to creating equipment which fits these requirements. From this point of view, specifically durability prediction allows to evaluate the potential of creating equipment with a long operating life. On early stages of equipment's development analytical methods of durability prediction are used. Obviously, the more precise the estimation is, the more likely that the practical test will confirm the durability predictions. Therefore, improving the engineering techniques of the durability prediction is a relevant problem.

Objective. The objective of this research is to improve the quality of design work by enhancing the engineering techniques of the durability prediction, which raise the authenticity of the evaluations.

Method. Life of the equipment are calculated using the statistical modelling method (Monte-Carlo method). This method takes into consideration probabilistic characteristics of constituent elements' life.

Results. As a result, the problem of predicting operating life of electronic equipment using the reference data on early stages of development is solved. An analysis of standardized method of durability prediction was performed which revealed existing limitations for using this method when predicting operating life of electronic equipment. An alternate, statistical method of predicting operating life of electronic equipment was suggested and a software implementation was created. Developed software was tested and verified. Analytical experiments were performed to show the authenticity of the suggested method and to compare it to the standardized one.

Conclusions. Thus, results of the performed research show that the standardized method is applicable only for calculating the minimum operating time. Also, it was concluded that the truncation parameter of element's life distribution, variation coefficient of life and some specific qualities of dependability prediction scheme have to be taken into consideration when predicting durability of electronic equipment.

KEYWORDS: electronic equipment, dependability, durability, life, design automation, simulation.

\section{NOMENCLATURE}

$\mathrm{EE}$ - electronic equipment;

TT - technical task;

$\mathrm{DM}$ - durability measure;

EC - electronic component;

DS - data sheet;

LS - limiting state;

$\mathrm{m}$ - mean;

g - group;

ASONIKA-K-D - software for calculating durability indicators of electronic equipment;

PK ASONIKA-K - software complex for calculating dependability indicators of electronic equipment;

$T_{p . \gamma}$ - gamma-percentile life;

$T_{H . M}-$ minimum operating time;

$P$ - probability;

$\overline{T_{p_{1}}}-$ life vector of electronic components;

$\overline{T_{p_{2}}}-$ life vector of the electronic components that reached the limit state;

$\chi_{y}$ - quantile of the normal distribution;

$\gamma$ - probability for which the life is calculated, expressed as a percentage;

$t_{p}-$ life;

$m\left(t_{p}\right)$ - mathematical expectation of life;

(c) Zhadnov V. V., Kulygin V. N., Zotov A. N., 2019

DOI 10.15588/1607-3274-2019-2-4 $\sigma\left(t_{p}\right)$ - standard deviation of life;

$v$ - variation coefficient of life;

$T_{p . m}$ - mean life;

$v_{m}-$ mean variation coefficient of life;

$v_{n}$ - variation coefficient of life of the $n$-th electronic component;

$N$ - number of electronic components in electronic equipment;

$m\left(t_{p}\right)_{n}$ - mathematical expectation of life of the $n$-th electronic component;

$\sigma\left(t_{p}\right)_{n}$ - standard deviation of life of the $n$-th electronic component;

$T_{p . \gamma n}-$ gamma-percentile life of the $n$-th electronic component;

$\gamma_{n}$ - probability for which the life of the $n$-th electronic component is calculated, expressed as a percentage;

$T_{H . M_{n}}$ - minimum operating time of the $n$-th electronic component;

$K_{L S}$ - limiting state criterion of electronic equipment;

$k$ - number;

$\hat{t}_{p_{k}}-k$-th life realization;

$\hat{t}_{p_{E E}}-$ life realization of electronic equipment; 
$\hat{t}_{p_{n}}-$ life realization of the $n$-th electronic component;

$l$ - number;

$\hat{t}_{p_{l}}-l$-th life realization;

$\gamma_{\ni M}$ - probability for which the life of electronic equipment is calculated, expressed as a percentage;

$M$ - number of simulation experiments;

$T_{p \cdot \gamma_{E E}}-$ gamma-percentile life of electronic equipment;

$x_{n}-n$-th realization of random variable;

$K_{L S_{g}}$ - limiting state criterion of reserved group;

$t_{p_{g}}-$ life realization of reserved group;

$N_{g}$ - number of electronic components in reserved group.

\section{INTRODUCTION}

Level of quality of renewable and modifiable electronic equipment largely depends on quality and effectiveness of engineering such equipment. This is a big factor in competitiveness on global and local markets. Moreover, this applies to modern on-board equipment of spacecraft which has complex operating algorithms, heightened dependability, noise immunity and persistence against external influences.

Besides, in addition to growing complexity of equipment and more strict requirements, time allotted for designing machinery is shortened. First stages of engineering are usually hindered by countless revisions and modification targeted not to raise the quality of equipment, but to eliminate flaws, defects and failures. This happens due to a number of shortcomings of traditional engineering process, mostly from insufficient integration of math modeling into modern information technology.

Main difficulties of using math modeling methods in engineering process come from two reasons. Firstly, methods of selecting and analyzing engineering decisions are not developed enough. In addition, malfunctions modeling and dependability-oriented engineering are often neglected. Secondly, there aren't many software packages to choose from, and their capabilities are limited.

Modern reliability calculation software packages (ASRN, "ARBITR", "Nadejnost" module of KOK complex, "Reliabilty" modules of CAD-systems, RAM Commander, WQS, BlockSim and others) focus mostly on reliability prediction, leaving durability out. However, these factors do matter a lot for spacecraft with its long lifespan, and for competitiveness on the market too.

It is known that durability is established with design, implemented with manufacturing and kept with maintenance. Better accuracy of durability characteristics evaluation on early stages of designing means more chances to construct durable equipment. This makes improving methods of durability characteristics calculation for equipment with heightened operating life a relevant problem.

(C) Zhadnov V. V., Kulygin V. N., Zotov A. N., 2019

DOI 10.15588/1607-3274-2019-2-4
This research examines standard procedure of equipment's life prediction and also methods, models and algorithms used for equipment durability analysis.

The objective of this research is to heighten equipment engineering quality by improving durability calculation method with durability probability characteristics of equipment's composite elements usage.

\section{PROBLEM STATEMENT}

Durability characteristics of equipment's components is the initial data for equipment operating life prediction. These characteristics are «minimum operating time» and «gamma-percentile life». Result of the calculations is the gamma-percentile life of electronic equipment which indicates the time during which equipment won't reach it's limiting state with gamma-probability. Limiting state criterion of electronic equipment is decided by a predetermined percentage of equipment's components reaching their life expectancy (in the worst-case scenario - of any component). Based on this, mathematical problem of equipment's operating life prediction comes to calculating equation (1) for $T_{p \cdot \gamma_{E E}}$ :

$$
\frac{\gamma}{100}=P\left(\overline{T_{p_{1}}} \geq T_{p \cdot \gamma_{E E}} \mid \overline{T_{p_{2}}} \leq T_{p \cdot \gamma_{E E}}\right)
$$

for worst-case scenario equation (1) becomes:

$$
\frac{\gamma}{100}=P\left(\overline{T_{p_{1}}} \geq T_{p \cdot \gamma_{E E}}\right)
$$

\section{REVIEW OF THE LITERATURE}

Many publications are devoted to the problems of equipment's operating life evaluation. They review three main methods of operating life prediction - experimental, analytical and experimental-analytical. Experimental methods rely on operational life testing (usually, accelerated testing) [1]. experimental-analytical methods assume that dependability tests are performed for a part of equipment's composing elements (usually in place developed elements), and the technical equipment's operating life itself is calculated. Since there is no equipment to test on early stages of engineering and the equipment consists of elements with known durability characteristics, these methods won't be reviewed. The most widespread durability assessment methods are the methods of calculating mechanical equipment's operating life under cyclic stressing, mechanical wear and other fatiguing stresses. These methods are used in calculating operating life of separate elements of equipment's carcass [2], which is a separate problem and it will not be reviewed here. There are also operating life prediction methods based on using probability-physical failure patterns [3, 4]. But using these methods also requires experimental tests of the component base, so they haven't found much use in engineering routine. 
Perhaps, the only document which regulates durability prediction on the stages of development is the standard [5], which is used ether directly (for example, [6]) or serves as a base for creating factory-local standards (for example, [7-9]).

Initial data for durability prediction using methods of this standard are the element's durability characteristics which are detailed and systematized in the handbook [10]. The handbook is an official publication and it gives a list of such experimentally obtained element's durability characteristics:

- gamma-percentile life;

- minimum operating time.

Fig. 1 shows a fragment of a Hand Book's table of resistor's durability characteristics.

However, minimum operating time values are detailed only for elements which have been produced under modern requirements. If an element is missing from the reference book, it has to be calculated using standard's [5] formula:

$$
T_{H . M}=\frac{1-0,15 \cdot \chi_{\gamma_{1}}}{1-0,15 \cdot \chi_{\gamma}} \cdot T_{p . \gamma}
$$

As implied by (3) methods of standard [5] assume that life of an element is a normally distributed random value:

$$
f\left(t_{p}\right)=\frac{1}{\sigma\left(t_{p}\right) \cdot \sqrt{2 \cdot \pi}} \cdot \int_{-\infty}^{+\infty} e^{-\frac{\left(t_{p}-m\left(t_{p}\right)\right)^{2}}{2 \cdot \sigma\left(t_{p}\right)^{2}}} d t_{p} .
$$

Clearly, the number 0.15 in formula (3) represents variation coefficient of life:

$$
v=\frac{\sigma\left(t_{p}\right)}{m\left(t_{p}\right)}
$$

It should be noted that in the document [7] value of $v$ is 0.25 , and in the document [8] -0.21 .

On top of that each of those documents assumes that the value of $v$ stays the same for every element when calculating durability characteristics. Therefore, if one elements has the same $\gamma$ value as some another element, but one of the elements has greater $T_{p . \gamma}$ value, other durability characteristics $\left(T_{p . m}\right.$ и $\left.T_{\mu . M}\right)$ will also be greater.

\begin{tabular}{|c|c|c|c|c|c|}
\hline $\begin{array}{l}\text { Type } \\
\text { products }\end{array}$ & $\begin{array}{c}\mathrm{d} \\
\text { pieces }\end{array}$ & $\begin{array}{l}\lambda_{\sigma} \cdot 10^{6} \\
1 / \text { hour }\end{array}$ & $T_{\text {H.M, in thousand hours }}$ & $\mathrm{T}_{\mathbf{p} . \gamma, \text { in thousand hours }(y=95 \%)}$ & $\begin{array}{l}T_{x p} \\
\text { year }\end{array}$ \\
\hline \multicolumn{6}{|c|}{$\begin{array}{l}\text { Resistors, constant, non-conductor } \\
\text { Metal-dielectric (except for precision) }\end{array}$} \\
\hline $\mathrm{P} 1-1^{*}$ & - & \multirow{8}{*}{0,049} & 25 (in all modes by DS) & 50 (in all modes by DS) & 15 \\
\hline P1-2* & - & & $\begin{array}{l}30 \text { (in all modes by DS) } \\
100\left(t \leq 60^{\circ} \mathrm{C}, \mathrm{P} / \mathrm{P}_{\mathrm{H}}=1\right)\end{array}$ & 60 (in all modes by DS) & 25 \\
\hline P1-3* & 0 & & $\begin{array}{l}15 \text { (in all modes by DS) } \\
100\left(t \leq 60^{\circ} \mathrm{C}, \mathrm{P} / \mathrm{P}_{\mathrm{H}}=1\right)\end{array}$ & 30 (in all modes by DS) & 15 \\
\hline $\mathrm{P} 1-5^{\star}$ & - & & $\begin{array}{l}15(\text { in all modes by DS }) \\
100\left(t \leq 60^{\circ} \mathrm{C}, \mathrm{P} / \mathrm{P}_{\mathrm{H}}=1\right)\end{array}$ & 30 (in all modes by DS) & 15 \\
\hline P1-8MП* & - & & 20 (in all modes by DS) & 40 (in all modes by DS) & 15 \\
\hline $\mathrm{P} 1-9^{*}$ & - & & $\begin{array}{l}50 \text { (in all modes by DS) } \\
\text { for } \mathrm{P} 1-9-40 \text { : } \\
100\left(\mathrm{t} \leq 85^{\circ} \mathrm{C}, \mathrm{P} \leq 16 \mathrm{BT}\right) \\
\text { for } \mathrm{P} 1-9-50 \text {; } \\
100\left(\mathrm{t} \leq 85^{\circ} \mathrm{C}, \mathrm{P} \leq 25 \mathrm{BT}\right)\end{array}$ & 100 (in all modes by DS) & 20 \\
\hline $\mathrm{P} 1-10^{*}$ & 0 & & $\begin{array}{l}800 \text { pulse } \mathrm{P} 1-10-1 \div \mathrm{P} 1-10-7 \\
20 \text { cycle } \mathrm{P} 1-10-7, \mathrm{P} 1-10-8 \\
\text { (in all modes by DS) }\end{array}$ & $\begin{array}{l}1200 \text { pulse } \mathrm{P} 1-10-1 \div \mathrm{P} 1-10-7 \\
30 \text { cycle } \mathrm{P} 1-10-7, \mathrm{P} 1-10-8 \\
\text { (in all modes by DS) }\end{array}$ & 15 \\
\hline $\mathrm{P} 1-21^{*}$ & - & & 6 (in all modes by DS) & $\begin{array}{l}12 \text { (in all modes by DS) } \\
(\gamma=90 \%)\end{array}$ & 12 \\
\hline
\end{tabular}

Dependability characteristics and reference data of individual types of resistors

Figure 1 - Hand Book "Nadyozhnost EhRI": part of a table with resistors' durability characteristics 
Calculation of variation coefficient for different types of elements shows that $v$ values lie in the range of $0.1 \div 0.25$. As example, Fig. 2 shows distribution of the variation coefficient for the "Receiving and converting cathode-ray tubes" class.

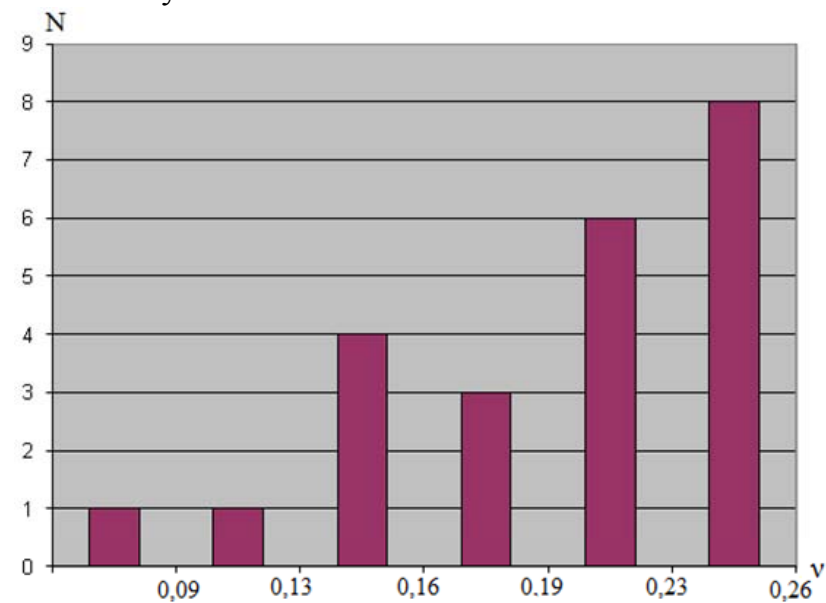

Figure 2 - Distribution of the variation coefficient diagram

So, if variation coefficients of life differ between elements, it can happen that one element has $T_{p . m}$ greater than another, and $T_{p, \gamma}$, in contrast, lesser.

To combat this, in [11] it has been suggested to use mean value of variation coefficient of life:

$$
v_{m}=\frac{\sum_{n=1}^{N} v_{n}}{N} .
$$

But neither documents [7, 8] nor monograph [11] detail evaluation of error, which is based on assumption of $v_{n}$ values equality.

Thus, one of the ways to increase durability prediction of equipment is using not determinate, but probabilistic characteristics of elements life.

\section{MATERIALS AND METHODS}

In order to resolve this problem a method of statistical modeling was used. This method is "a universal method of calculation for objects of any structure, for any distributions of operating time between failures and restoration times, for any strategies and methods of restoration and preventive maintenance..." [12].

In this case statistical modeling included following stages:

- Calculating parameters of the life distribution $\left(m\left(t_{p}\right)_{n}\right.$ и $\left.\sigma\left(t_{p}\right)_{n}\right)$ using values of $T_{p . \gamma n}, \gamma, T_{\text {н.un }}$ and $\gamma_{1}=99.9 \%$ for each element (using normal distribution law).

- Performing simulation modeling:

- Calculating life realization for each element (using Box-Muller transform);

- Calculating life realization for equipment using limiting state criterion $\left(K_{L S}\right)$. The limiting state criterion in standard [5] is interpreted as reaching operating life limit by a defined percentage of total count of equipment. Us-

(C) Zhadnov V. V., Kulygin V. N., Zotov A. N., 2019 DOI 10.15588/1607-3274-2019-2-4 ing this limiting state criterion for equipment's life realization means life realization's vector is aligned in ascending order. A value with number $k$ is chosen from this vector:

$$
\hat{t}_{p_{E E}}=\hat{t}_{p_{k}}
$$

where $k$ is

$$
k=\left[\frac{K_{L S}}{100} \cdot \operatorname{int}(N)\right]+1
$$

Obviously, if the limiting state criterion is formulated as "reaching lifespan by any element", then, with this limiting state criterion:

$$
\hat{t}_{p_{E E}}=\min _{n=1, N}\left(\hat{t}_{p_{1}}, \hat{t}_{p_{2}}, \ldots, \hat{t}_{p_{N}}\right) .
$$

- Carrying out simulation experiment and forming a vector of life realizations of electronic equipment

- Calculating $\gamma$-percentile life of electronic equipment. Aligning the vector of life realizations in descending order and selecting a value with number $l$ from it:

$$
T_{p \cdot \gamma_{E E}}=\hat{t}_{p_{l}},
$$

where $l$ is

$$
l=\left(1-\frac{\gamma}{100}\right) \cdot M
$$

This method was implemented and included in ASONIKA-K-D system of ASONIKA-K software package [13].

Fig. 3 shows results of modeling operating life of P1-1 resistor, which has $T_{\mu . M}=25$ thousand of hours, $T_{p . \gamma}=50$ thousand of hours $(\gamma=95 \%)$, amount of simulation experiments $-10^{6}$.

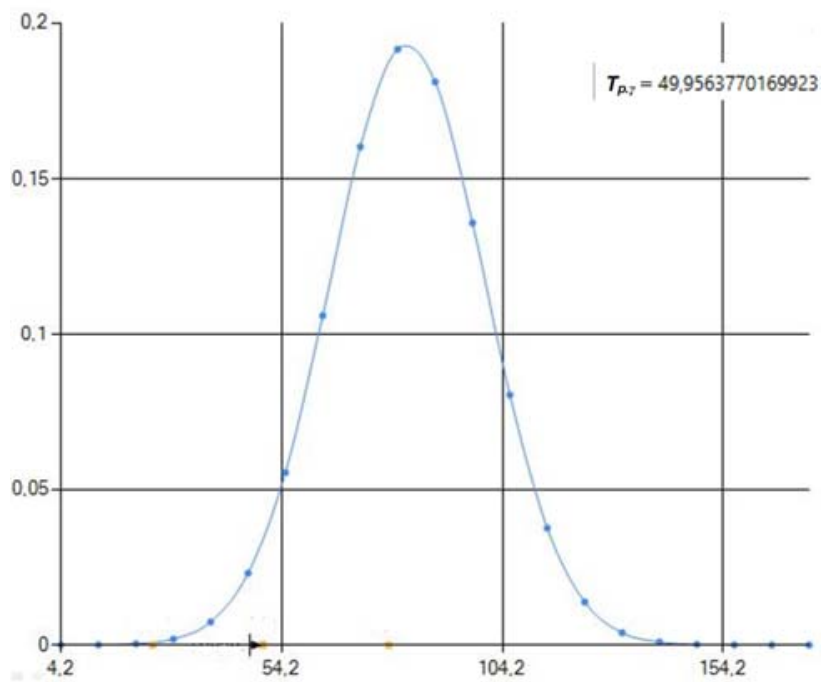

Figure 3 - Results of P1-1 resistor life modeling 
As seen in Fig. 3, statistically modelled value of resistor's $95 \%$ operating life (49.956 thousands of hours) almost coincides with predetermined one.

\section{EXPERIMENTS}

To evaluate the influence of variation coefficient of life a number of calculations inside ASONIKA-K-D system was carried out.

Case 1. Equipment contains 5 elements with $T_{p . m}=50$ thousands of hours $(v=0.25)$ and 5 elements with $T_{p . m}=40$ thousands of hours $(v=0.1), K_{L S}=0 \%$

Case 2. Equipment contains 5 elements with $T_{p . m}=50$ thousands of hours and 5 elements with with $T_{p . m}=40$ thousands of hours, $K_{L S}=0 \%$. The variation coefficient for each element equals $v_{m}$, which is calculated using formula (6).

Case 3. Equipment contains 10 "P1-1" resistors (depicted in Fig. 1), $K_{L S}=0 \%$.

To evaluate the accuracy of calculations using a method described in standard [5], a 95\% operating life calculation example was chosen.

The equipment consists of 101 resistors, 34 nonelectrolytic capacitors, 28 electrolytic capacitors, 22 silicon diodes, 14 low-powered silicon transistors, 5 highpowered transistors, 37 microchips with low degree of integration, black and white kinescope and 2 lowfrequency transformers. limiting state criterion: "No more than $20 \%$ of elements should have their operating life used up".

Since standard [5] does not include types of elements, they were chosen match standard's [5] example. That means choosing elements in a way that makes the count of elements with $95 \%$ life's value to fit with the standard's [5] example. Formed data is summarized in Table 1 .

\section{RESULTS}

Results of calculating 95\% life's value for case 1 are shown in Fig. 4a. Calculations were performed using ASONIKA-K-D system with a number of simulation experiments $M=10^{6}$.

Fig. 4 b shows Results of calculating 95\% life's value for case 2.

Results of calculating 95\% life's value for case 1 are shown in Fig. 5. Calculations were performed with a number of simulation experiments $M=10^{6}$.

Fig. 6a illustrates results of calculating 95\% life's value calculated using ASONIKA-K-D system with a number of simulation experiments $M=10^{6}$ for $K_{L S}=20 \%$. Fig. $6 \mathrm{~b}$ shows results of calculating equipment's $95 \%$ life's value for $K_{L S}=0 \%$.

Table 1 - Initial data for calculating 95\% life of equipment

\begin{tabular}{|c|c|c|c|c|c|c|c|}
\hline \multirow[b]{2}{*}{ № } & \multirow[b]{2}{*}{ Type products } & \multirow{2}{*}{$\begin{array}{c}\mathrm{T}_{\mathrm{H}, \mathrm{M}}, \\
\text { in thousand } \\
\text { hours }\end{array}$} & \multirow{2}{*}{$\begin{array}{c}\mathrm{T}_{\mathrm{p}, \gamma}(\gamma=95 \%), \\
\text { in thousand hours }\end{array}$} & \multirow{2}{*}{$\begin{array}{c}\text { Number of } \\
\text { pieces }\end{array}$} & \multirow[b]{2}{*}{ All pieces } & \multicolumn{2}{|c|}{ Data [1] } \\
\hline & & & & & & $\begin{array}{c}T_{p, \gamma} \\
(\gamma=95 \%)\end{array}$ & $\begin{array}{c}\text { Total percent- } \\
\text { age }\end{array}$ \\
\hline 1 & 2 & 3 & 4 & 5 & 6 & 7 & 8 \\
\hline \multicolumn{5}{|c|}{ Ceramic capacitors for rated voltage $1600 \mathrm{~V}$ and higher } & \multirow{4}{*}{25} & \multirow{4}{*}{ before 10000} & \multirow{4}{*}{100} \\
\hline 1 & K15-15 & 2 & 5 & 24 & & & \\
\hline \multicolumn{5}{|c|}{ Monochrome picture tubes } & & & \\
\hline 2 & 2ЛК1Б & 2 & $9(\gamma=90 \%)$ & 1 & & & \\
\hline & & Electrolyti & acitors & & \multirow{4}{*}{26} & \multirow{4}{*}{ “15000 } & \multirow{4}{*}{89.6} \\
\hline 3 & К50-20 & 10 & 13 & 1 & & & \\
\hline \multicolumn{5}{|c|}{ Thermoresistors } & & & \\
\hline 4 & KMT-1 & 10 & $15(\gamma=90 \%)$ & 25 & & & \\
\hline & & Volumetric-po & capacitors & & \multirow{4}{*}{37} & \multirow{4}{*}{ “20000 } & \multirow{4}{*}{79} \\
\hline 5 & K52-2 & 10 & 15 & 27 & & & \\
\hline \multicolumn{5}{|c|}{ Ceramic capacitors for rated voltage $1600 \mathrm{~V}$ and higher } & & & \\
\hline 6 & К15-14в & 7.5 & 15 & 10 & & & \\
\hline & & sistors, constal & etal-dielectric & & \multirow{4}{*}{37} & \multirow{4}{*}{ “30000 } & \multirow{4}{*}{63.9} \\
\hline 7 & $\mathrm{C} 2-6$ & $\begin{array}{l}15 \\
\end{array}$ & 25 & 35 & & & \\
\hline & & ow-voltage po & transformers & & & & \\
\hline 8 & TAH & 12 & 27.5 & 2 & & & \\
\hline \multicolumn{5}{|c|}{ Integrated microcircuits } & \multirow{10}{*}{95} & \multirow{10}{*}{ “50000 } & \multirow{10}{*}{48.8} \\
\hline 9 & Hybrid & 25 & 50 & 37 & & & \\
\hline & & Low-power sil & transistors & & & & \\
\hline 10 & $2 \mathrm{~T} 317 \mathrm{~A}$ & 25 & 50 & 14 & & & \\
\hline & & Silicon rec & diodes & & & & \\
\hline 11 & Д214 & 25 & 50 & 22 & & & \\
\hline \multicolumn{5}{|c|}{ Powerful silicon transistors } & & & \\
\hline 12 & $2 \mathrm{~T} 808 \mathrm{~A}$ & 25 & 50 & 5 & & & \\
\hline \multicolumn{5}{|c|}{ Resistors, constant, metal-dielectric } & & & \\
\hline 13 & $\mathrm{P} 1-12$ & 25 & 40 & 17 & & & \\
\hline & & sistors, constal & etal-dielectric & & 24 & “60000 & 9.9 \\
\hline 14 & P1-4 & 30 & 60 & 24 & & & \\
\hline & & & & Total: & 244 & & \\
\hline
\end{tabular}




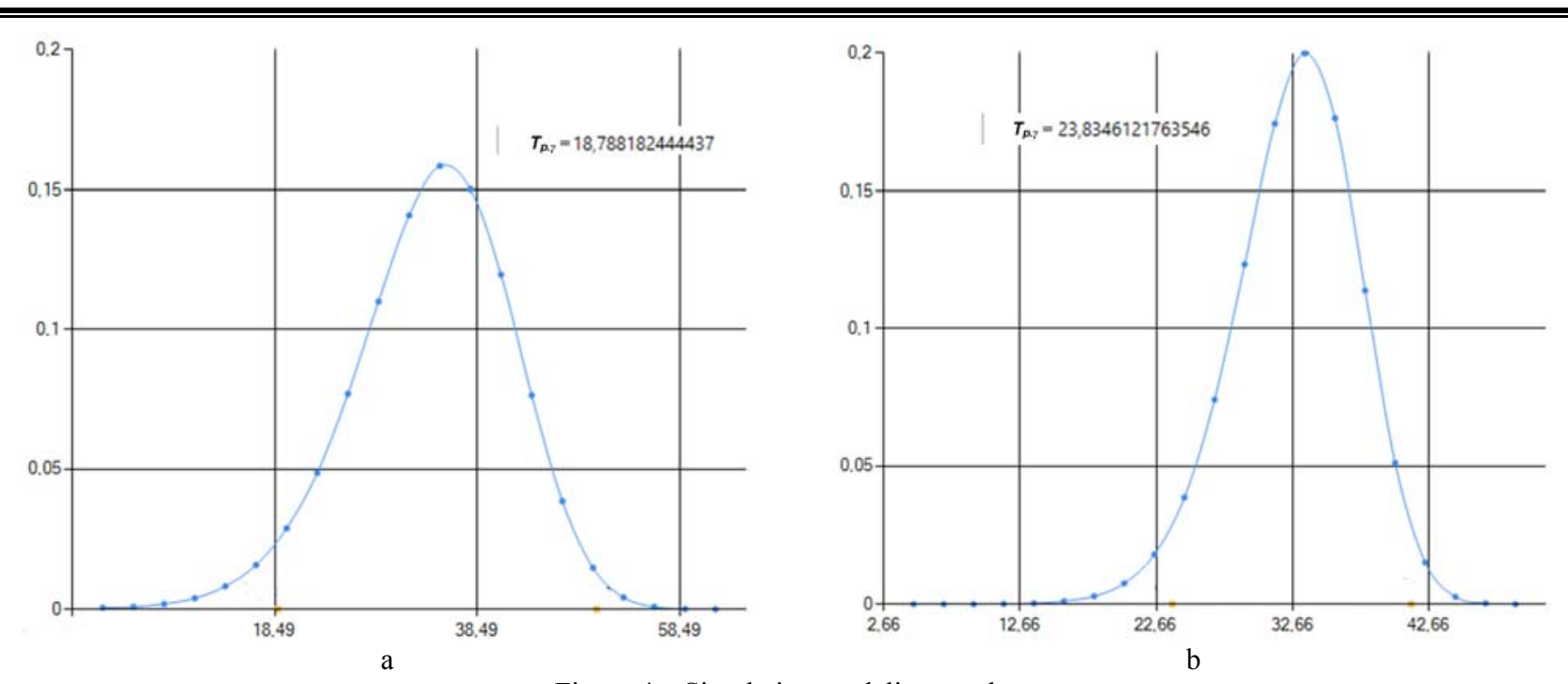

Figure 4 - Simulation modeling results:

$\mathrm{a}-$ for values $v_{1-5}=0.1$ and $v_{6-10}=0.25 ; \mathrm{b}-$ for values $v_{1-10}=v_{m}=0.175$

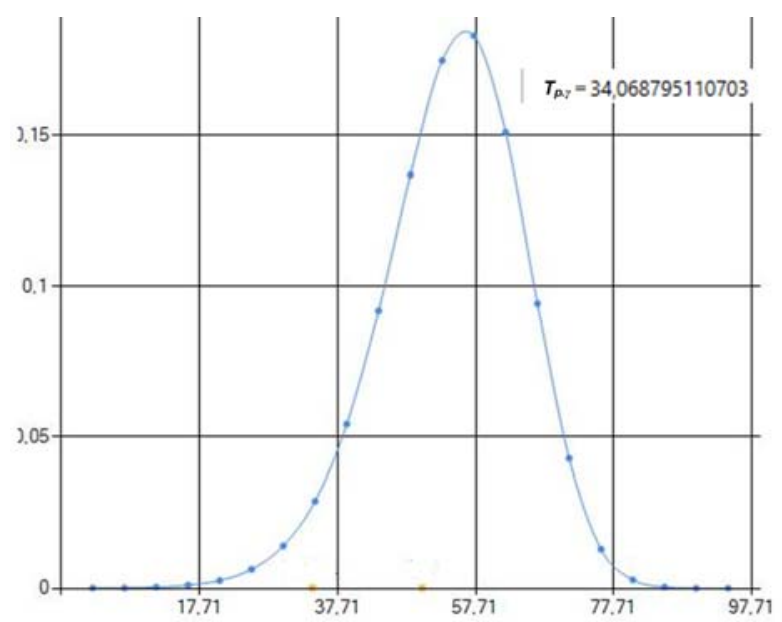

Figure 5 - Simulation modeling results for a unit with 10 resistors
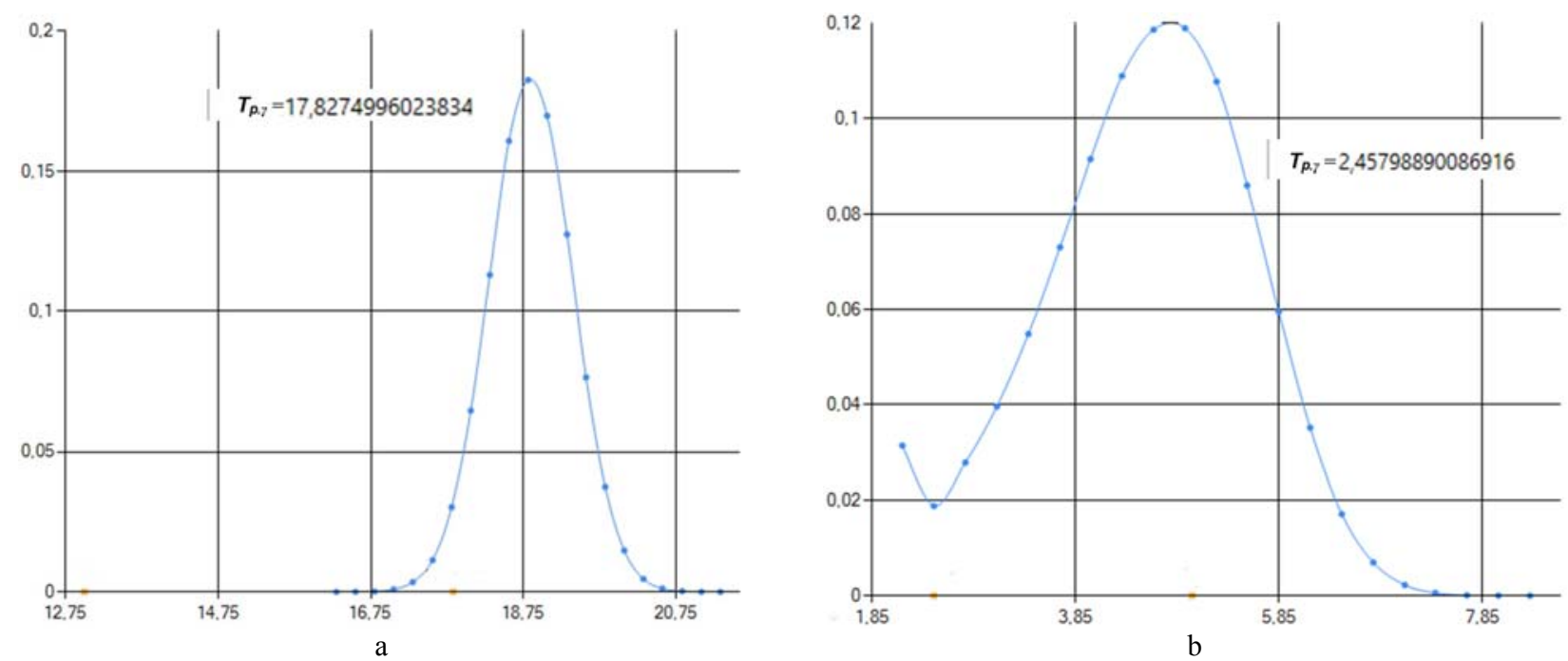

Figure 6 - Simulation modeling results: $\mathrm{a}-$ for $K_{L S}=20 \%$; - for $K_{L S}=0 \%$ 


\section{DISCUSSION}

To determine the cause of discrepancy between results of statistical modeling and standard's [5] example a test example was calculated (Fig. 4)

As Fig. 4a illustrates, the value of $95 \%$ life is equal to 18,788 thousands of hours. For comparison, Fig. 4b shows the value of $95 \%$ life of the same equipment with $v$ for each element equal to $v_{m}$, which is calculated using formula (6). As shown in Fig. 4b, the value of $95 \%$ life $(23,834$ thousands of hours) differs from the one with using different $v$ values as shown in Fig. 6a

However the calculated values are substantially lower than the value of $95 \%$ life calculated using standard's [5] method (33.42 thousands of hours)

A calculation of a test example was performed to identify the reason behind such results of statistical modeling (see Fig. 5). As illustrated in Fig. 5, the value of 95\% life is equal to 34.068 thousands of hours, but standard's [5] result is 50 thousands of hours.

Since the $v_{n}$ values in this case are same for all elements, this discrepancy is due to different elements' life values being independent random values.

When modeling independent random values (elements' lifes), for each element a random value is generated $\left(x_{1}, x_{2}, \ldots, x_{N}\right)$ and it's used to calculate the life's value $\left(t_{\mathrm{p} 1}, t_{\mathrm{p} 2}, \ldots, t_{\mathrm{p} N}\right)$ as shown in Fig. 7.

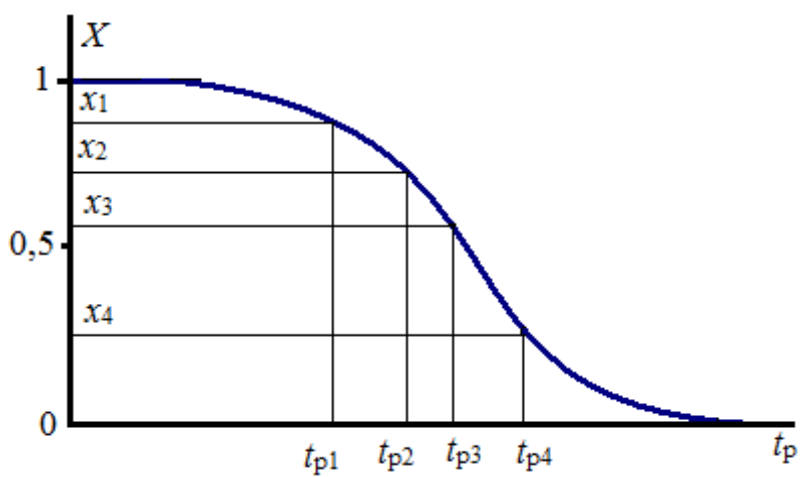

Figure 7 - Modeling of elements' lifes

Removing discrepancy between results of statistical modeling and standard's [5] method can be achieved by not only making $v_{n}$ values equal, but also creating functional relation between elements of different types. That means if the first element's life realization equals to $t_{p 1}$ for a random value equal to $x$, then values of life realizations of other elements $\left(t_{p 1}, t_{p 2}, \ldots, t_{p N}\right)$ must be the same (illustrated in Fig. 8).

However, this is impossible in practice. It is hard to imagine skipping one type of element life verification but checking all of the others when building equipment. Specifically it has to be verification of elements life which would guarantee the element's life with probability close to 1 .

Thus, if elements life are independent values, the probability of equipment's life being no lower than a certain value would decrease with increasing equipment's elements count.

(C) Zhadnov V. V., Kulygin V. N., Zotov A. N., 2019

DOI 10.15588/1607-3274-2019-2-4

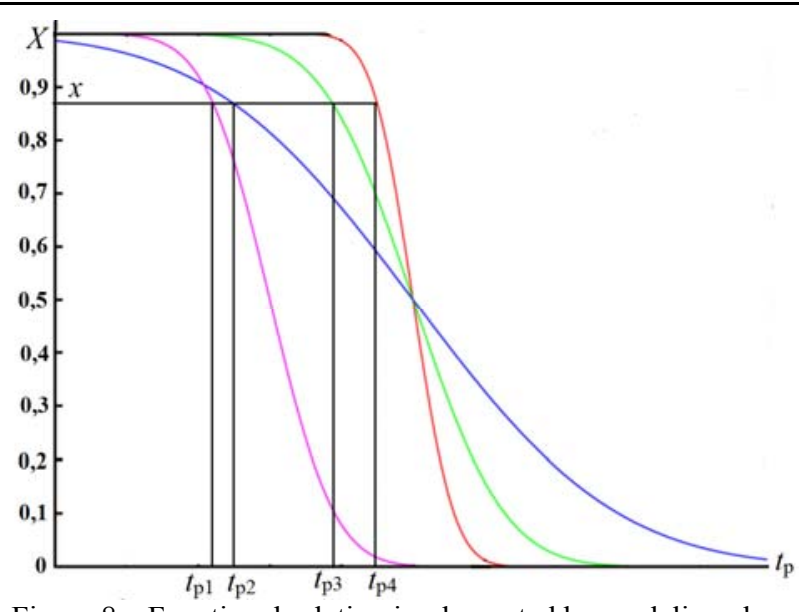

Figure 8 - Functional relation implemented by modeling elements' lifes realizations

This can lead to calculated value of $95 \%$ equipment's life being lower than the gamma-percentile life calculated using standard's [5] method. Minimum operating time would be lower too.

It should be noted that the value $\gamma=99.9 \%$ in formula (3) should be considered as an approximate one. Such value is recommended in standard [5] for calculating $T_{\text {н.м }}$ of elements with no $T_{\mu . M}$ values given in Data Sheet. By definition, minimum operating time is a time period (life) during which limiting state of an element won't happen with a probability of 1 . Which means it should be considered as a shift parameter for life distribution function (Fig. 9).

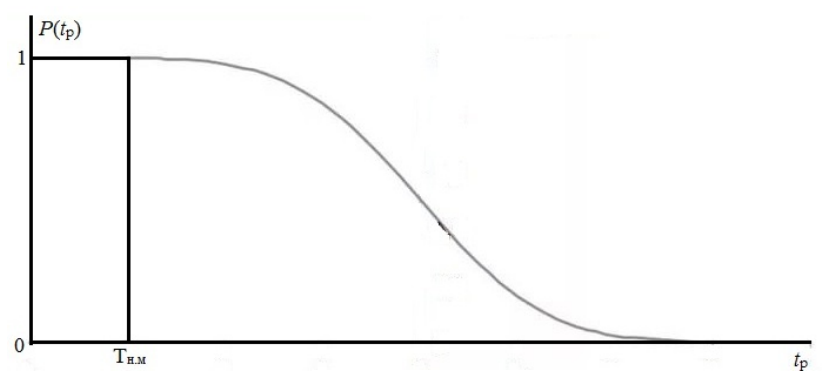

Figure 9 - Life distribution function

To confirm this, let's find $\chi_{\psi 11}$ value using formula (3). In accordance with requirements of current standards, $95 \%$ element's life should be no lower than it's doubled minimum operating time. Let's assume $T_{p \cdot \gamma}=2 \cdot T_{\mu . u}$. In this case, formula (3) will take the following form:

$$
T_{H . M}=\frac{1-0,15 \cdot \chi_{\gamma_{1}}}{1-0,15 \cdot 1,645} \cdot 2 \cdot T_{H . M} .
$$

Solving (12) for $\chi_{\gamma 1}$ gives $\chi_{\gamma 1}=4,1568$. For this value the probability is almost equal to 1 (at $\chi=4.265$ $\gamma=99.999 \%)$.

Based on this, it should be assumed that the element's life distribution function is shifted by $T_{H, M}$ value. In this 
case, statistical modeling of element's life realization should be performed using formula:

$$
\hat{t}_{p_{n}}=\left\{\begin{array}{l}
\hat{t}_{p_{n}}=\hat{t}_{p_{n}}, \hat{t}_{p_{n}} \geq T_{H \cdot M_{n}}, \\
\hat{t}_{p_{n}}=T_{H \cdot M_{n}}, \hat{t}_{p_{n}}<T_{H \cdot M_{n}} .
\end{array}\right.
$$

With taking into account all of the correction, statistical modeling was performed for standard's [5] example.

As illustrated in Fig. 6 a, 95\% equipment's life is no lower than 17.827 thousands of hours, which is 1.4 times greater than the one calculated using standard's method (13 thousands of hours).

Besides, Fig. $6 \mathrm{~b}$ shows results of calculating $95 \%$ equipment's life for $K_{L S}=0 \%$. Fig. 7 b shows that $95 \%$ equipment's life is no lower than 2.457 thousands of hours, which is 2 times less than the one calculated using standard's [5] method (5 thousands of hours).

It should be noted that existence of reserved elements (reserving using additional (reserve) elements) should be taken into consideration when modeling equipment's life realizations.

For example, limiting state criterion for constantly loaded reservation is formulated as "Expending operating life of $100 \%$ of elements included in reserved group". $K_{L S}$ value for such reserved group will be equal to:

$$
K_{L S_{g}}=100 \% \text {. }
$$

Calculating realizations of reserved group for such $\mathrm{K}_{\mathrm{LS}}$ value is performed using following formula:

$$
\hat{t}_{p_{g}}=\max _{n=1, N_{g}}\left(\hat{t}_{p_{1}}, \hat{t}_{p_{2}}, \ldots, \hat{t}_{p_{N_{g}}}\right)
$$

\section{CONCLUSIONS}

Thus, performed studies and analytical experiments allow us to draw the following conclusions:

- value of minimum operating time as a minimum of integral element's minimum operating time can be used for "lowest" estimation of gamma-percentile life of nonreserved equipment;

- standard's [5] method of calculating equipment's durability is applicable for calculating gamma-percentile life only if it's proven that lifes of integral elements have strong correlative connection and equal variation coefficients;

- statistical modeling is the most reasonable way of analytical gamma-percentile life calculation only if life of integral elements are independent random values with different parameters of their distributions;

- laws of life distribution with shift parameters equal to the minimal operating time should be used for modeling element's life realizations;

- existence of reserved elements (reserving using additional (reserve) elements) should be taken into consideration when modeling equipment's life realizations.
- specialized software should be used to calculate gamma-percentile life of equipment (like ASONIKA-KD).

In conclusion, it should be noted that aforementioned method of statistical modeling does not take into consideration elements' life dependence from equipment's operation model. Particularities of predicting life of elements whose total flow of failures consists of independent failure flows of its components. These problems are reviewed in detail in [11] and [14]. Their suggested models will be implemented with ASONIKA-K-D further development.

\section{ACKNOWLEDGEMENTS}

This research carried out in 2015 was supported by "The National Research University 'Higher School of Economics’ Academic Fund Program” grant (№ 15-050029).

\section{REFERENCES}

1. Piganov M. N. Ispytaniya ehlektronnyh sredstv specialnogo naznacheniya [elektronnyj resurs]: elektron. ucheb. posobie. Samara, Samar. gos. aehrokosm. un-t im. S. P. Koroleva (nac. issled. un-t), 2012. elektron. tekstovye i graf. dan. (1,86 Mbajt). 1 ehl. opt. disk (CD-RW).

2. Talickij E. N. Zashchita ehlektronnyh sredstv ot mekhanicheskih vozdejstvij. Vladimir, Izd-vo Vladim. gos. un-ta, 2001, $256 \mathrm{p}$

3. Druzhinin G. V. Nadezhnost avtomatizirovannyh sistem. Moscow, Energiya, 1977, 536 p.

4. Strelnikov V. P. Veroyatnostno-fizicheskie metody issledovaniya nadezhnosti mashin i apparatury, Nadezhnost $i$ kontrol kachestva, 1989, No. 9, pp. 3-7.

5. Apparatura radioehlektronnaya. Opredelenie pokazatelej dolgovechnosti: OST 4.012.013-84 [Vveden 1985-07-01]. Moscow, VNII, 1985, 14 p. (Otraslevoj standart).

6. Sistema menedzhmenta kachestva. Proektirovanie i razrabotka. Poryadok vypolneniya i metodiki raschyot nadyozhnosti na stadii razrabotki: STO OmGTU 73.03-2012 [Vveden 2012-11-26]. Omsk, OmGTU, 2012, 49 p. (Standart universiteta).

7. Metodika ocenki srednego sroka sluzhby izdelij raschyotnym metodom: E10.012.054-87, [Vveden 1987-01-01]. Moscow, VNII, 1987, 20 p. (Normativnyj dokument).

8. Standart predpriyatiya. Metodika rascheta pokazatelej nadezhnosti radioehlektronnoj apparatury: STP YuFKV.025-2004 [Vveden 2004-05-18]. Moscow, NTC Modul, 2004, 31 p. (Standart predpriyatiya).

9. Standart predpriyatiya. Sistema upravleniya kachestvom razrabotok izdelij. Apparatura fizicheskih izmerenij. Apparatura i kompleksy apparaturnye. Raschyot pokazatelej nadyozhnosti i sostava ZIP: STPS 101-85 (izm. 2000), [Vveden 2000-12-12]. Moscow, NIIT, 2000, 63 p. (Standart predpriyatiya).

10. Nadyozhnost EhRI: Spravochnik. Moscow, MO RF, 2006, $641 \mathrm{p}$.

11. Zhadnov V. V. Raschyot nadezhnosti ehlektronnyh modulej: nauchnoe izdanie. Moscow, «Solon-Press», 2016, 232 p.

12. Nadyozhnost v tekhnike. Raschyot nadyozhnosti. Osnovnye polozheniya: GOST 27.301-95 [Vveden 1997-01-01]. Moscow, IPK Izdatelstvo standartov, 1995, 16 p. (Gosudarstvennyj standart Rossijskoj Federacii). 
13. Iofin A., Zhadnov V. Comparative characteristics of the PC ASONIKA-K and reliability calculations programs, Modern Problems of Radio Engineering, Telecommunications and Computer Science: Proceedings of the International Conference TCSET'2014, Dedicated to the 170th Anniversary of Lviv Polytechnic National University. Lviv, National University "Lviv Polytechnic", 2014, pp. 226-228.
14. Ivanov I., Korolev P., Polesskiy S., Zhadnov V.V. The Design Procedure of Specified Operating Life of Fiber-optic Cables, Radio Electronics, Computer Science, Control, 2016, No. 2 (37), pp. 7-14.

Received 19.03.2018. Accepted 12.06.2018.

УДК 621.396.6, 621.8.019.8 МЕТОД ПРОГНОЗУВАННЯ ПОКАЗНИКІВ ДОВГОВІЧНОСТІ ЕЛЕКТРОННИХ ЗАСОБІВ

Жаднов В. В. - канд. техн. наук., доцент, професор Департаменту електронної інженерії Національного дослідницького університету «Вища школа економіки», Москва, Росія.

Кулигін В. Н. - магістр техніки і технологій, аспірант Аспірантської школи 3 технічних наук Національного дослідницького університету «Вища школа економіки», Москва, Росія.

Зотов А. Н. - магістр техніки і технологій, аспірант Аспірантської школи 3 технічних наук Національного дослідницького університету «Вища школа економіки», Москва, Росія.

\section{АНОТАЦІЯ}

Актуальність. Постійне підвищення вимог до строків активного існування космічних апаратів вимагає створення електронних засобів, що відповідають цим вимогам. 3 цієї точки зору саме показники довговічності дозволяють оцінити принципову можливість створення електронних засобів тривалого функціонування. На ранніх етапах проектування для оцінки показників довговічності застосовуються розрахункові методи. Очевидно, що чим точніше оцінка, тим більша ймовірність того, що при випробуваннях зразків показники довговічності будуть підтверджені. Тому вдосконалення інженерних методик оцінки показників довговічності електронних засобів є актуальним завданням.

Мета роботи. Підвищення якості проектних робіт за рахунок вдосконалення інженерних методик розрахунку ресурсу електронних засобів, що дозволяють підвищити точність і достовірність його оцінки.

Метод. Для розрахунку ресурсу електронних засобів застосований метод статистичного моделювання (метод МонтеКарло), що дозволяє враховувати імовірнісні характеристики ресурсу комплектуючих елементів.

Результати. Розв’язана задача прогнозування ресурсу електронних засобів на основі довідкових даних про характеристиках довговічності елементів на ранніх етапах проектування. Проведено аналіз стандартизованого методу розрахунку показників довговічності і виявлення істотні обмеження цього методу при прогнозуванні ресурсу електронних модулів. Запропоновано альтернативний метод прогнозування ресурсу електронних модулів, заснований на статичному моделюванні, і створена його програмна реалізація. Проведено тестування розробленого програмного забезпечення. Проведено обчислювальні експерименти 3 дослідження достовірності запропонованого методу і його порівняння із стандартизованим методом.

Висновки. За результатами проведених експериментів показано, що стандартизований метод можна застосовувати тільки для розрахунку мінімального напрацювання і зроблено висновок про необхідність врахування параметра усічення розподілу ресурсу елементів і коефіцієнта варіації ресурсу, а також особливостей схеми розрахунку надійності при прогнозування показників довговічності електронних засобів.

КЛЮЧОВІ СЛОВА: електронний засіб, надійність, довговічність, ресурс, автоматизація проектування, імітаційне моделювання.

УДК 621.396.6, 621.8.019.8

\section{МЕТОД ПРОГНОЗИРОВАНИЯ ПОКАЗАТЕЛЕЙ ДОЛГОВЕЧНОСТИ ЭЛЕКТРОННЫХ СРЕДСТВ}

Жаднов В. В. - канд. техн. наук, доцент, профессор Департамента электронной инженерии Национального исследовательского университета «Высшая школа экономики», Москва, Россия.

Кулыгин В. Н. - магистр техники и технологий, аспирант Аспирантской школы по техническим наукам Национального исследовательского университета «Высшая школа экономики», Москва, Россия.

Зотов А. Н. - магистр техники и технологий, аспирант Аспирантской школы по техническим наукам Национального исследовательского университета «Высшая школа экономики», Москва, Россия.

\section{АННОТАЦИЯ}

Актуальность. Постоянное повышение требований к срокам активного существования космических аппаратов требует создания электронных средств, отвечающих этим требованиям. С этой точки зрения именно показатели долговечности позволяют оценить принципиальную возможность создания электронных средств длительного функционирования. На ранних этапах проектирования для оценки показателей долговечности применяются расчетные методы. Очевидно, что чем точнее оценка, тем больше вероятность того, что при испытаниях образцов показатели долговечности будут подтверждены. Поэтому совершенствование инженерных методик оценки показателей долговечности электронных средств является актуальной задачей.

Цель. Повышение качества проектных работ за счет совершенствование инженерных методик расчета ресурса электронных средств, позволяющих повысить точность и достоверность его оценки. 
Метод. Для расчета ресурса электронных средств применен метод статистического моделирования (метод МонтеКарло), позволяющий учитывать вероятностные характеристики ресурса комплектующих элементов.

Результаты. Решена задача прогнозирования ресурса электронных средств на основе справочных данных о характеристиках долговечности элементов на ранних этапах проектирования. Проведен анализ стандартизованного метода расчета показателей долговечности и выявленные существенные ограничения этого метода при прогнозировании ресурса электронных модулей. Предложен альтернативный метод прогнозирования ресурса электронных модулей, основанный на статическом моделировании и создана его программная реализация. Проведено тестирование разработанного программного обеспечения. Проведены вычислительные эксперименты по исследованию достоверности предложенного метода и его сравнение со стандартизованным методом.

Выводы. По результатам проведенных экспериментов показано, что стандартизованный метод применим только для расчета минимальной наработки и сделан вывод о необходимости учета параметра усечения распределения ресурса элементов и коэффициента вариации ресурса, а также особенностей схемы расчета надежности при прогнозирования показателей долговечности электронных средств.

КЛЮЧЕВЫЕ СЛОВА: электронное средство, надежность, долговечность, ресурс, автоматизация проектирования, имитационное моделирование.

\section{ЛІТЕРАТУРА / ЛИТЕРАТУРА}

1. Пиганов М. Н. Испытания электронных средств специального назначения [электронный ресурс]: электрон. учеб. пособие / М. Н. Пиганов. - Самара : Самар. гос. аэрокосм. ун-т им. С. П. Королева (нац. исслед. ун-т), 2012. - Электрон. текстовые и граф. дан. (1,86 Мбайт). 1 эл. опт. диск (CD-RW).

2. Талицкий Е. Н. Защита электронных средств от механических воздействий / Е. Н. Талицкий. - Владимир : Издво Владим. гос. ун-та, 2001. - 256 с.

3. Дружининин Г. В. Надежность автоматизированных систем / Г. В. Дружининин. - М. : Энергия, 1977. $536 \mathrm{c}$.

4. Стрельников В. П. Вероятностно-физические методы исследования надежности машин и механизмов / В. П. Стрельников // Надежность и контроль качества. 1989. - № 9. - С. 3-7.

5. Аппаратура радиоэлектронная. Определение показателей долговечности : ОСТ 4.012.013-84. - Введ. 1985-0701. - М. : ВНИИ, 1985. - 14 c.

6. Система менеджмента качества. Проектирование и разработка. Порядок выполнения и методики расчет надежности на стадии разработки : СТО ОмГТУ 73.032012. - Введ. 2012-11-26. - Омск : ОмГТУ, 2012. - 49 с.

7. Методика оценки среднего срока службы изделий расчетным методом : Е10.012.054-87. - Введ. 1987-01-01. М. : ВНИИ, 1987. -20 c.
8. Методика расчета показателей надежности радиоэлектронной аппаратуры : СТП ЮФКВ.025-2004. - Введ. 2004-05-18. - М. : НТЦ Модуль, 2004. - 31 с.

9. Система управления качеством разработок изделий. Аппаратура физических измерений. Аппаратура и комплексы аппаратурные. Расчет показателей надежности и состава ЗИП : СТПС 101-85 (изм. 2000). - Введ. 2000-1212. - М. : НИИТ, 2000. -63 с.

10. Надежность ЭРИ: Справочник - М. : МО РФ, 2006. $641 \mathrm{c}$.

11. Жаднов В. В. Расчет надежности электронных модулей: научное издание / В. В. Жаднов. - М. : «Солон-Пресс», 2016. $-232 \mathrm{c}$.

12. Надежность в технике. Расчет надежности. Основные положения: ГОСТ 27.301-95. - Введ. 1997-01-01. - М. : ИПК Издательство стандартов, 1995. - 16 с.

13. Iofin A. A. Comparative characteristics of the PC ASONIKA-K and reliability calculations programs / A. A. Iofin, V. V Zhadnov // Modern Problems of Radio Engineering, Telecommunications and Computer Science: Proceedings of the International Conference TCSET'2014, Dedicated to the 170th Anniversary of Lviv Polytechnic National University. - Lviv : National University «Lviv Polytechnic», 2014. - P. 226-228.

14. The Design Procedure of Specified Operating Life of Fiberoptic Cables / I. A. Ivanov, P. S. Korolev, S. N. Polesskiy, V. V. Zhadnov // Radio Electronics, Computer Science, Control. - 2016. - № 2 (37). - P. 7-14. 